\title{
Revitalization Model of Balai Latihan Kerja (BIk) For Improving Knowledge, Education, And Skills Based On Link And Match
}

\author{
RM. Moch. Wispandono ${ }^{1 *}$, Eni Sri Rahayu Ningsih ${ }^{2}$, Deni S.B Yuherawan ${ }^{3}$, and Netty \\ Dyah $^{4}$ \\ ${ }^{1}$ Lecturer in Business and Economics Faculty, University of Trunojoyo Madura, Indonesia \\ ${ }^{2}$ Lecturer in Business and Economics Faculty, University of Trunojoyo Madura, Indonesia \\ ${ }^{3}$ Lecturer in Law Faculty, University of Trunojoyo Madura, Indonesia \\ ${ }^{4}$ Lecturer in Culture and Social Science Faculty, University of Trunojoyo Madura, Indonesia
}

\begin{abstract}
The vocational training center (Balai Latihan Kerja/BLK) has great potential to improve the quality of Indonesian workers. The existence of this BLK is increasingly strategic with the support of the government. This can be seen from the large number of BLKs scattered in each regency city in Indonesia. However, now the conditions of the BLK are very concerning, both in terms of the effectiveness of the use, the quality of the Training Center and the use of the BLK function. On the other hand, the condition and quality of Indonesian Migrant Workers (BMI) is very alarming. Based on research by the Center for Regional Studies of the University of Brawijaya, it was found that the majority of them did not have the skills needed in the destination country. This is compounded by their lack of knowledge about market analysis of needs (skills) in the destination country. From this fact, there is no link and match between migrant workers and the BLK of each region. This study aims to find a model that can minimize the weakness of handling migrant workers and increase their work productivity
\end{abstract}

\section{Introduction}

The vocational training center (Balai Latihan Kerja/BLK) has great potential to improve the quality of Indonesian labor. The existence of this BLK is increasingly strategic with the support of the government. The functions of the BLK include (a) preparing plans, programs, budgets, evaluations and reporting; (b) implementation of labor training; (c) conducting training program trials, and labor competency tests; (d) institutional cooperation and preparation of reports. The number of BLKs is spread in each provincial city and district in Indonesia. However, now the condition of the BLK is quite alarming. Based on the standpoint of the Ministry of Manpower and Transmigration, it shows that almost 100 percent of BLKs in Eastern Indonesia are poor, in Central Indonesia region 3.8 percent are

\footnotetext{
* Corresponding author: wispandono@trunojoyo.ac.id
} 
good, 27.2 percent are moderate and 75 percent are bad and in the West Indonesia 15.7 percent are good, 37,3 percent is moderate and 47 percent is bad. Nationally the BLK with good conditions was only 11.1 percent, moderate conditions were 30.2 percent and bad conditions were 58.7 percent.

On the other hand, the condition and quality of Indonesian Migrant Workers (BMI) is very alarming. Some of the problems faced by BMI include culture, language and communication, low performance of BMI, violence, rape, termination of unilateral contracts, substandard wages, overstay, pregnancy and having children and lesbian issues. This happens because the average quality (input) of BMI is very low. Lack of knowledge, education and skills and protection makes them experience violence in the destination country.

This condition of BMI does not really need to happen if these migrant workers are given skills in the BLK of each region. The vocational training center should be the responsible facilitator to take care of the needs of migrant workers who will go abroad. Services provided include administrative services and practical services. But the fact is ironic, the condition of BLK in Indonesia is very alarming starting from the aspect of management, the quality of human resources, facilities and infrastructure, curriculum, and weak networks to the lack of care of the local government. Based on the facts above, this study offers a study of revitalization of vocational training centers to improve the knowledge, education and skills of migrant workers with the concept of link and match.

The revitalization study of the BLK is also very urgent because based on the facts, the condition of the Madurese (migrant workers) workforce is very alarming. Troubled Indonesian Workers from East Java in 2014 were dominated by Madurese with a total of around 3,519 people (metrotvnews.com). Four districts in Madura, according to Disnakertransduk East Java records, enter the five regions with the highest rate of migrant workers in East Java (Data from East Java Disnakertransduk 2015). Throughout 2014, there were 7,493 Indonesian migrant workers (BMI) from East Java who were in trouble, ranging from minor to severe violations. "Of that amount, around 70\% percent are from Madura (Edi Purwinarto, 2015). The problematic TKIs included Sampang, Pamekasan and Sumenep. For Sampang there are 15.61 people, Pamekasan is 1129, Sumenep 829 TKI (Head of the East Java Provincial Government's Dinakertransduk, 2015).

The problem of this research is how to build a revitalization model of the Work Training Center (BLK) as a place to increase the knowledge, education and skills of migrant workers who have the concept of link and match.

Based on these problems, the steps taken in this study are: (1) identifying training programs at the Vocational Training Center (2) analyzing the potential and problems of human resources and facilities and infrastructure at the Vocational Training Center (3) identifying, analyzing stakeholders (private, government, academics) who have the opportunity to become BLK partners (4) analyze the training and management models at BLK based on the needs of the labor market and migrant workers, and (5) formulate a link and match based training center institutional strengthening model.

\section{Method}

The design of the research used is descriptive qualitative with data collection techniques adjusted to the data to be collected and the intended data source. Research locations in Bangkalan, Sampang, Pamekasan and Sumenep. The population in this location is BLK, Disnakertrans and prospective BMI with purposive sampling technique (sample technique). This research is expected to produce a BLK revitalization model as an effort to improve BMI skills and expertise. Data collection in this study was carried out with several steps, namely: In-depth interviews and observations conducted to collect data about the needs and 
problems of vocational training centers. While data on the level of knowledge, education and skills of BMI were collected through questionnaires, observations and in-depth interviews. To test the validity of the data triangulation method is used, both source triangulation and theory triangulation.

\section{Results and discussion}

The beginning of the establishment of the BLK came from the idea of establishing the Industrial Training Program Training Center (PLKPPI) in the field of industry in 1953. In 1960, the PLKPPI was directed to become an Employee Job Seekers Training in order to become skilled workers. In 1970, along with the times, there was a change from the Industrial Training Program Training Center (PLKPPI) to become a Training Center under the guidance of the Minister of Manpower of the Republic of Indonesia. And since the regional autonomy of the Vocational Training Center (BLK) has changed to the Regional Work Training Center (BLKD) under the auspices of the Managing Unit (UPT) of the Manpower Service in each region in Indonesia.

The Dinas Technical Implementation Unit (UPTD) of the Social Service, Manpower and Transmigration Office of Bangkalan Regency was established in 2012. The background of the establishment of the BLU UPTD in the service area was due to classic problems that emerged in Bangkalan district which were almost the same as in other regions in Indonesia is a lot of prospective applicants / job seekers who do not have adequate abilities and competencies as requested by users. The encouragement and demands of the workforce / industry (users) so that the government can facilitate the availability of prospective applicants / job seekers who can fulfill the qualifications they need is another reason for the existence of BLK so that the formation of BLK is intended to conduct training and guidance for job seekers to have abilities and competencies as expected by users. This is in accordance with the main task of the UPTD BLK Dinsosnakertrans Bangkalan which has the task of carrying out some technical activities in the field of skills, knowledge and administration training and management of Occupational Training Centers located under and responsible to the Bupati through the Head of Social Services, Manpower and Transmigration.

The BLK in Sampang District was established in 2014. The BLK was originally under the Office of Social, Manpower and Transmigration (Dinsosnakertrans). In this service there is a field of labor. Activities in the workforce are synonymous with training and job creation, including TKI (Indonesian Workers). Because the activities were related to training, it was deemed ineffective if they were in the Social Service Office. Finally, in 2013, they began designing the Vocational Training Center (BLK), then in 2014 the BLK was officially established. (interview with Pak Bisrul Hafil, BLK Sampang). Initially the BLK participated in the Dinsosnakertrans, but in the nomenclature of the 2016-2017 fiscal year, the BLK was sheltered by the Office of Cooperatives, Micro and Manpower Enterprises, to be exact on December 28, 2016. Based on interviews with informants, several data were obtained including strengths, weaknesses, opportunities and threats.

The Job Training Center in Sumenep Regency, which was renamed the Job Training Institute, but later returned to being a Sumenep BLK established since 1981 and is among the oldest on the island of Madura. This BLK was directly under the guidance of the East Java provincial government and so far it has been able to produce 2832 alumni who have been successfully trained in various skill fields, namely: graphic design, automotive, workshop, makeup, sewing, and office tools. Sumenep BLK currently has a total of 18 staff and 6 instructors / trainers (but 4 people have full-time status but are still needed when there are training activities). The BLK built on an area of 2.5 hectares has several buildings including office space (BLK leaders and staff), prayer rooms, and the main room / building 
for training (workshop space), such as workshop, automotive, make-up, sewing, besides also having classrooms (for the delivery of material in class before practice). Each training is scheduled to be held for one month (holidays on Saturday and Sunday) or 240 hours of effective training for which training materials include theory $(20 \%)$ and practice $(80 \%)$ so that training activities are in the classroom (for theory) and at workshops / workshops (for practice). Each type of training has its own classrooms and workshops with a fairly good arrangement of space both in terms of lighting and air circulation so that trainees feel comfortable to attend training

Based on interviews with informants, obtained some data including strengths, weaknesses, opportunities and threats.

\subsection{Programs available at the BLK}

The training program at the Center for Training is diverse. The training programs in this BLK included embroidery and sewing, there were 3 automotive, there were cars, motorbikes, ships, carbide welding and electric welding and batik. (interview with Pak Bisrul Hafil, BLK Sampang). Some programs that have been held by Job Training Centers (BLK) are manjahit, border, automotive (car, motorcycle, ship), carbide welding, electric welding and batik. The target of training is the general public with criteria: poor people, migrant workers who fail to leave, unemployment, productive age (17-40 years). (interview with Pak Bisrul Hafil, BLK Sampang).

Meanwhile, according to Pak Suhardi (Head of Sumenep BLK) that the routine agenda programmed in the DIPA UPT of Sumenep Work Training is under the auspices of the East Java Provincial Government. This agenda is held annually in various fields of training, where the Sumenep Job Training Unit provides skills in vocational fields: Graphic design, Automotive engineering (R2 and R4), Electric welding techniques, Refrigeration, Beauty (cosmetics), Technical support, Cooking, sewing, electrical engineering, embroidery techniques, building engineering, creative industries, automotive motorbike engineering, screen printing techniques, and business management. If organized based on funds from DIPA, the implementation has been proposed a year before for the field of training needed by the community / world of work where the trainees are job seekers.

The mechanism for disseminating information, namely the BLK, provided socialization in each sub-district attended by the Village Head from each of these sub-districts. So most trainees were recruited from the village head. There are also those who register themselves here, but rarely. The target is after training, the community is able to create jobs with the expertise they get. Because after they finish training they are provided with equipment according to the training program they take. For example, sewing, they get a sewing machine. Motorcycle training, participants get motorcycle and car repair equipment. The equipment is free. Starting from registration, consumption, residence equipment, certificates and transport money.

There are many programs that are in the Job Training Center (BLK). There is training in automotive, electric welding, carbide, sewing, building or trading and computers.

The following is an excerpt of the interview with Mr. Agus Sumarso:

"A lot of training has been given by the BLK to the participants, including training in the automotive sector, which is divided into 3 branches, namely motorbikes, cars, and ships which are often called outboard motors. Then there is electric welding and carbide welding, embroidery and sewing, building or carpentry, batik, also once there was computer training ". 


\subsection{Stakeholders who have the opportunity to become partners}

One of the BLK stakeholders who played a role was PT CTKI. This is because the majority of prospective migrant workers register at PT CTKI. So the one providing training to prospective migrant workers is PT CTKI. This then caused no BLK program from the Office of Cooperatives, Micro Enterprises and Employment specifically for prospective TKI. This is in accordance with the results of interviews conducted with Mr. Bisrul Hafil:

"Until now there hasn't been one. The problem is handled by PT. CTKI. We also collaborate with them. Most prospective migrant workers register directly to PT. CTKI, then from PT. CTKI requested a report to us and also reported prospective TKI who registered at the PT. Some register directly with us, but only a little. Sometimes there are only 15 people registered, but those who get to other countries can be hundreds. Yes it's illegal, bro. Until now, there have been around 90\% of TKI illegal in Kab. Sampang itself ".

Based on the data above, most prospective migrant workers register directly with PT CTKI. PT CTKI asks for recommendations to the Office and reports prospective migrant workers who apply to the PT. Some TKIs have registered directly with the Dinas, but very few. Sometimes those who register are only 15 people, but those who get to other countries can be hundreds (illegal). Up to now there are around 90\% of illegal TKI from Sampang. The Office does not provide training programs specifically for prospective migrant workers, because PT CTKI has handled the problem of TKI training. The role of Dinas is only to provide information on the Indonesian labor market in the sub-district to the public regarding illegal TKI.

Furthermore, one of the stakeholders who is very instrumental is Trunojoyo Madura University, which has a special handling unit on labor issues (in accordance with one of the fields in UTM's Tehno Park Science namely employment and women) such as the Center for BUSINESS INCUBATORS and Career Development and Entrepreneurship. The Center (CDEC) contributes as an expert in providing training and certification about HR management, training management and experts in legislation related to migrant workers. Experts at CDEC consist of academics and practitioners from Management Sciences, Development Economics, Law, Communication, Engineering from the Faculties in the Trunojoyo Madura University.

\subsection{Potential and problems of HR and infrastructure at the job training center}

Some of the potential in the Job Training Center (BLK) include:

a. The BLK facilities in the four districts in Madura are adequate and complete. Each room is used for one training (both theory and practice), the room is also adequate, starting in 2016/2017 there is a dormitory for trainees and also a dining room, prayer room, bathroom.

b. The programs have also been quite good and there are additional programs this year, namely batik.

c. The location of the BLK is strategic because it is in the middle of the city and on the edge of the highway so it is easily accessible by the community.

d. According to the observations regarding the services provided to the trainees it was quite good, including the services provided to the guests (when we visited there it was served well).

e. The community is enthusiastic about programs from the BLK. It is proven by each training the participants reach maximum capacity (20 people).

f. There is support from the district and sub-district governments, so the program runs smoothly. 
Apart from strengths, there are some weaknesses that are still inherent in the Vocational Training Center (BLK). These weaknesses include:

a. For HR (BLK employees). At around 2:45 a.m. WIB when the researchers arrived at the BLK, it turned out that the hall seemed deserted, only a few employees were still in place until the hour came home.

b. Facilities and infrastructure for office space are inadequate. Because one standard size room is occupied by 6 employees. And also in the door computer training room was broken.

c. Programs from BLKs that come into contact with Indonesian labor migrants are still lacking, as there has not been any specific training from BLK for prospective migrant workers.

d. There are no special instructors for each district so that the training activities are slowed down.

e. There is no Manpower Office in Sampang District. The existence of the Employment field is sheltered by the service of micro and labor business cooperatives. This was felt to be out of tune, so that the programs adjusted to the BLK program (There was no specific program in the field of labor).

f. Needs needed at Sampang BLK are instructors. Because of the 4 districts in Madura, there are only instructors in Sumenep. This is as stated by the following Head of BLK:

"Of the 4 regencies in Madura, the only instructor was Sumenep, because he was directly sheltered by Surabaya. Well, one instructor was shared with other districts, so that it was not effective. (interview with Agus Sumarso) "

g. According to the regent. Keteenaga Kerjaan "Bisrul Hafi" Most of the Sampang people, especially in the North, do business in the sale and purchase of illegal drugs. So that makes them lazy to work well.

h. In connection with the revitalization of the Work Training Center in addition to the HR aspect, public awareness about the importance of certificate of expertise is very lacking. Communities that have expertise certificates from the BLK do not function the certificate as well as possible. The following is an excerpt from the official interview with Pak Bisrul Hafil Sampang.

"In addition to human resources, awareness from the community is still lacking. Like TKI, there are still many who are illegal. They just come along when there is an invitation without taking care of the papers and other requirements. Even though they have a certificate of expertise provided by the BLK, they don't function the certificate as well as possible ". (interview with Mr Bisrul Hafil, Sampang)

\subsection{Training and management model at BLK}

The condition of the BLK in the four districts located on the island of Madura is adequate, both facilities and buildings. In 2016-2017 there is a dormitory as a place for lodging participants during training. Equipment is also adequate, such as sewing, computer, welding, carpentry, automotive etc. There is no program from the Office that relates to improving worker skills for prospective migrant workers abroad because there is already a PT CTKI that handles skills training for prospective migrant workers. (interview with Pak Agus Sumarso).

Initially, the BLK was under the auspices of the Office of Social and Manpower, but starting in 2016, the BLK was under the auspices of the Office of Cooperatives, Micro Enterprises and Employment, which previously were under the auspices of the Office of Social and Manpower (interview with Mr. Agus Sumarso ) 


\subsection{Employment training center institutional strengthening model}

To design a model of BLK institutional strengthening, it must be based on strengths and weaknesses (threats)

a. The programs of the BLK did not touch the needs of Indonesian migrant workers. There has been no specific training from BLK for prospective TKI.

b. The program for prospective TKI has only been carried out by PT CTKI

c. There are no special instructors for each Regency. So that it slows down the implementation of training activities.

d. Needs are needed in all three BLKs (outside the Sumenep BLK), namely instructors.

e. Public awareness about the importance of certificate of expertise is very lacking. Communities that have expertise certificates from the BLK do not function the certificate as well as possible.

Based on the previous analysis, it was obtained an illustration of the BLK institutional strengthening model, namely the BLK must coordinate (cooperation) with PT CTKI in terms of training prospective migrant workers. So that the training programs at the BLK synergize with PT CTKI, namely training and improving the skills of prospective migrant workers. In addition, the people who want to register as TKI must have at least a skill certificate obtained from the BLK. This will not only ease the task of PT CTKI in training the community (prospective TKI) as well as preparing the community to be better prepared in the world of work.

The condition of the BLK in the four districts located on the island of Madura is adequate, both facilities and buildings. In 2016-2017 there is a dormitory as a place for lodging participants during training. Equipment is also adequate, such as sewing, computer, welding, carpentry, automotive etc. There is no program from the Office that relates to improving worker skills for prospective migrant workers abroad because there is already a PT CTKI that handles skills training for prospective migrant workers. (interview with Pak Agus Sumarso).

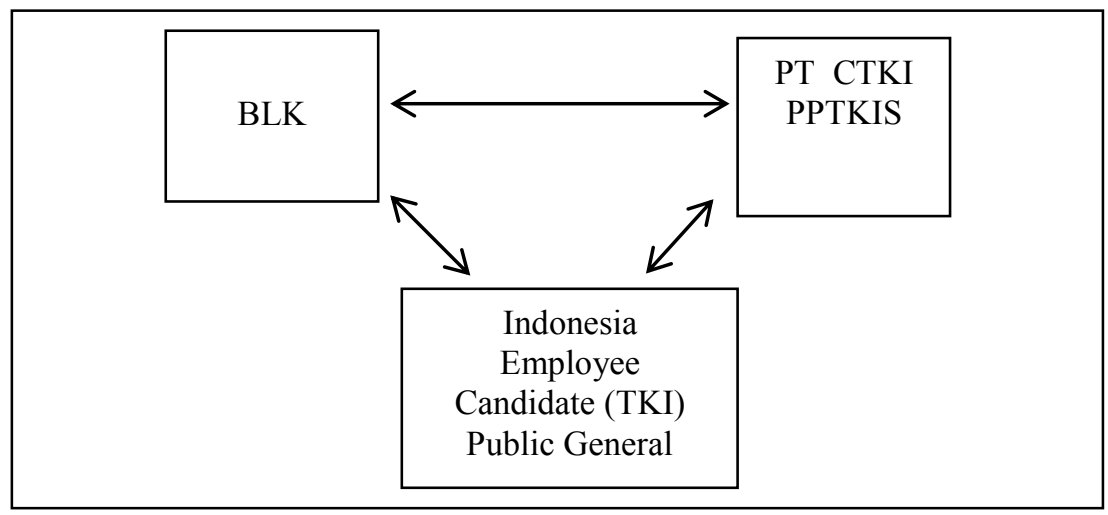

The target of training at the BLK is not to find work for graduates but rather to obtain skills by being trained for about one month on a working day with the duration of the training starting at 08.00 to 16.00 or equivalent training held for 240 hours per class. The training participants at the BLK are not limited to only the residents of Bangkalan (Madura) but may from outside the Bangkalan district as long as the person concerned has a KTP and is around 18 years to 35 years old.

BLK registration is usually opened at the beginning of the year, the requirements are such as a copy of a high school / equivalent diploma, a copy of an SKCK, a photocopy of an ID card, an original doctor's certificate, and a photo that must be completed. By registering at the beginning of the year students who graduate from high school or 
equivalent who wish to register must wait for 6 months, (it can be said that prospective participants are rested before facing a solid schedule). BLK training also does not require students to become workers because with the skills they have, students can open a business to open employment opportunities. So BLK becomes a motor in reducing unemployment. The lack of a blocking BLK program, which is the lack of information on BLK in high schools, the scheme is actually waiting instead of picking up the ball, the BLK is lagging behind with recruitment which is usually carried out by private schools and universities ahead of national examinations by going to schools - the upper secondary school. Not to mention the selection carried out through written examinations which actually denied the literal meaning of the Vocational Training Center. Because the BLK should be an extension of the regional government to help the government alleviate unemployment through education, the cost of which has already been borne by the government. For this reason, the government, according to the Minister of Manpower, Hanif Dhakiri will continue to strive and encourage competency improvement for workers through various strategies to improve BLK quality through reorientation, revitalization and rebranding of BLK.

First, the reorientation of the BLK related to the priority sector in the BLK, there must be a priority sector including the profession. Second, revitalization of BLK to improve quality so that BLK graduates can meet industrial needs. Third, the rebranding of BLK in order to increase public trust is higher. Thus, unemployed people get the opportunity to have skills and can enter the labor market. While those who have worked, can improve their competencies so that their competitiveness increases.

Especially for revitalization, the Ministry of Manpower continues to revitalize BLK, especially BLK-BLK owned and managed by regional governments (pemda). The Ministry of Manpower's Director General of Training and Productivity Development (Binalattas) Khairul Anwar (March, 2016) said the effort was made so that BLK was able to keep up with technological advances and the needs of the labor market and industry. Some aspects that have been addressed in revitalizing this BLK include infrastructure and training equipment, quantity and quality of instructors, training methods and curriculum, and management of BLK management. Binalattas targets to revitalize 70 BLK in 2016 so that the quality of Indonesian workers will be better so as to accelerate the reduction of unemployment and increase the competitiveness of workers at both the national and international levels.

Those who are trained and educated in BLK besides formal workers are also potential entrepreneurs. Although to educate and train someone to become an entrepreneur is much more difficult than training and educating skilled formal workers. The types of training that are in demand include computer vocational training, electric welding vocational education, vocational education, vocational automotive, sewing vocational, vocational embroidery, and vocational carpentry. Through competency-based job training in BLK, it is expected that Indonesian labor migrants entering the labor market both in the local, national and foreign labor markets can continue to be upgraded and ready to win competition in the MEA era.

Training at BLK generally only takes about one month or is identical with around 240 hours per class. Training with a sufficient duration of time is indeed inseparable from the addition of funds, labor, and space as well as the understanding of the training itself that distinguishes it from education. Training (training) is a short-term educational process that uses systematic and organized procedures so that non-managerial workers learn the knowledge and technical skills for specific purposes. Job training according to Act No. 13 of 2003 Article I Paragraph 9. is the whole activity to give, obtain, improve, and develop work competencies, productivity, discipline, attitudes, and work ethic at a certain level of skills and expertise in accordance with the level and job qualifications and jobs. 
According to Marzuki Training is teaching or giving experience to someone to develop behavior (knowledge, skill, attitude) in order to achieve something desired. Training for employees is a process of teaching certain knowledge and skills and attitudes so that employees are more skilled and able to carry out their responsibilities better, according to standards.

The training is more focused on improving the capabilities and expertise of HR related to jabtan or functions that are the responsibility of the individual concerned at this time (current job oriented). The goal to be achieved and a training program is to improve individual performance in the current position or function. In the science of human resource management (HRM) training and / or education is usually a package and is one of the main tasks of HRM in the field of HR development. It is said that development is the second operational function of personnel management, the development of new / old employees needs to be carried out in a planned and continuous Employee development program should be carefully arranged and based on scientific methods and guided by the skills needed by the company or an educational institution now and for the future. Every company personnel / education institution is required to work effectively, efficiently, quality and quantity of work well so that the competitiveness of a company / educational institution is greater.

So the definition of development is an effort to improve the technical, theoretical, conceptual, and moral capabilities of employees in accordance with the needs of work / position through education and training. In addition, development (development) can also be interpreted as preparing individuals to assume different or higher responsibilities in companies, organizations, institutions or educational institutions. Development tends to be more formal, involving anticipation of individual abilities and expertise that must be prepared for future office interests. The targets and development programs involve a broader aspect, namely increasing the ability of individuals to anticipate changes that might occur unplened change or planed change. From this understanding shows that the focus of career development is to increase the mental ability of the workforce. Development is more focused on increasing ability in decision making and expanding human relations for top management and middle level management while training is intended for employees at lower levels (executors).

According to Hasibuan (2012) the notion of practice and development is different. Training is intended to improve the mastery of a variety of specific, detailed and routine work skills and techniques, in which training prepares employees (labor) to do the work now. While the development (Developrnent) has a wider scope in an effort to improve and improve knowledge, abilities, attitudes and personality traits.

According to Mariot Tua Efendi H (2005) that training and development can be defined as a planned effort from the organization to improve the knowledge, skills and abilities of employees. Furthermore, Tua Mariot added that training and development are the same two concepts, namely to improve knowledge, skills and abilities. But, judging by its purpose, generally the two concepts can be distinguished. Training is more emphasized in increasing the ability to do specific jobs at this time, and development is more emphasized in increasing knowledge to do work in the future.

\section{Conclusion}

BLK is a forum that prepares prospective workers or entrepreneurs with various skills needed by the world of work / industry so that BLK graduates are expected to have good field competencies in terms of knowledge, skills, and attitudes (behaviors) that are tailored to their talents, interests, and work goals desired by prospective graduates. Therefore, the role of BLK needs to be improved with one of them is to revitalize BLK to increase the knowledge, education and skills of prospective workers. The revitalization of the BLK 
began with an inventory of the problems and constraints faced by the BLK and prospective workers as well as the potential and strength that exists by looking at the opportunities and threats that exist in the labor market both nationally and internationally.

Based on the inventory, needs analysis is then carried out based on the relevance and comparability between the provision of theory and practice provided as long as they take part in education or training at the BLK with real conditions in the workforce / industry. The results obtained were the establishment of a BLK revitalization model for increasing knowledge, education, and skills of prospective workers. The resulting model has also considered institutional strengthening including the support of stakeholders. 


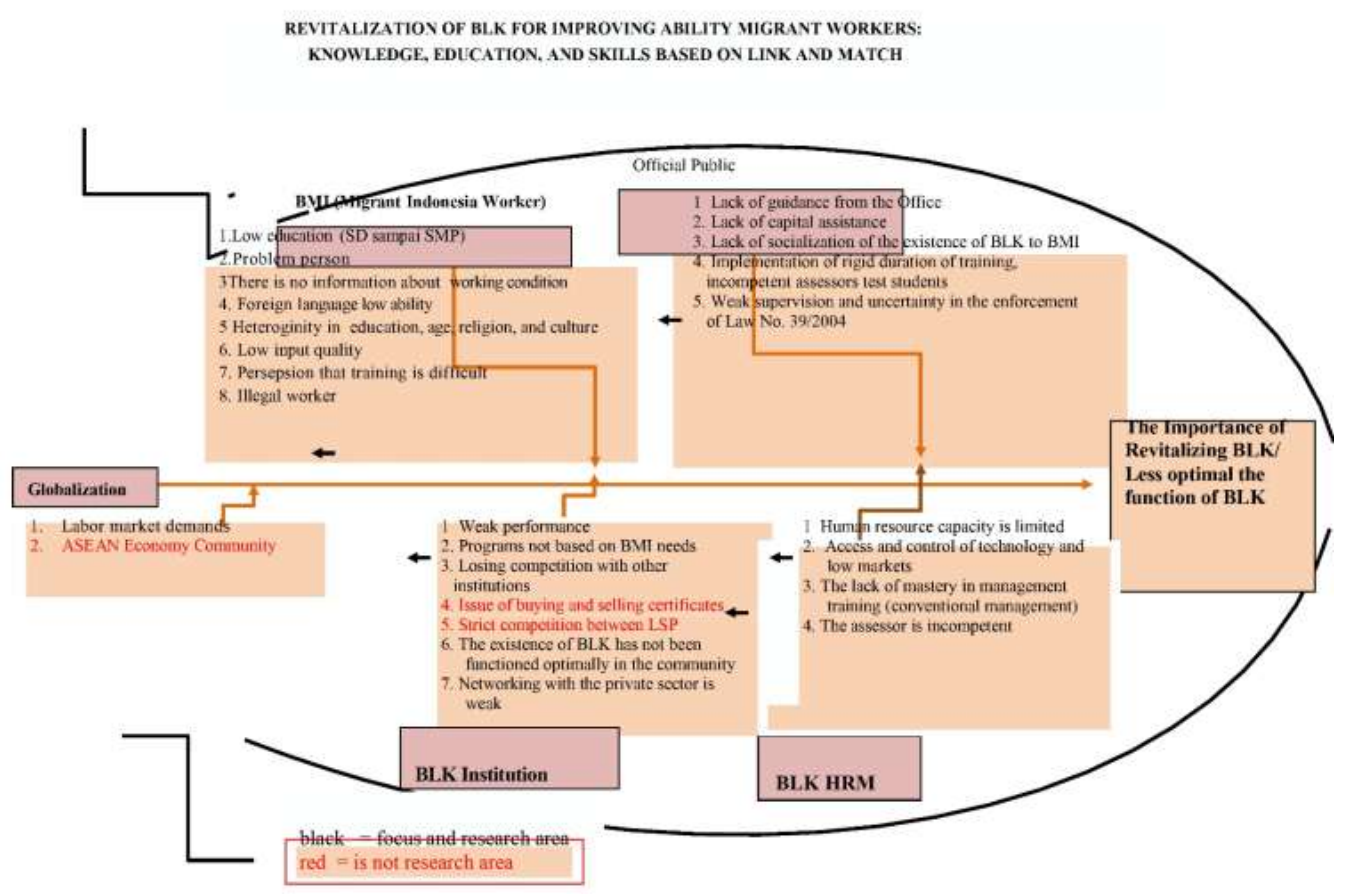




\section{Bibliography}

[1] A. Ahmad, E. Journal of Goverment (2014)

[2] A. Mangkunegara and A. Prabu, Human Resource Management (PT. Refika Aditama, Bandung, 2006)

[3] A. Pandji, Business Management (PT. Asdi Mahastya, Jakarta, 2000)

[4] Data on Disnakertransduk of the East Java Provincial Government, 2015

[5] E. Maesaroh and M. Sulton, E.journal.unikama Method (2015)

[6] H. Fitroh, J. of Public Admin 1, (2010)

[7] I. Jusuf, Basic Principles of Training Management (From Need Analysis to Training Program Evaluation), (Scholar Human, Jakarta, 2001)

[8] Interview with Pak Bisrul Hafil, Sampang BLK. Interview with Mr. Agus Sumarso (53 years old)

[9] M. Sjafri, Strategic Human Resource Management (Ghalia Indonesia, Jakarta, 2004)

[10] M.S.P Hasibuan, Human Resource Management Jakarta: Teenagers Rosdakarya Nailasuhada-m.blogspot.com/.../pelatihan-dan-pengembangan-sumberdayamanusia, accessed 20 November 2013

[11]M. S.P Hasibuan, ibid, 86.

[12]M. Tua Efendi H, Manusa Resource Management: procurement, development, compensating, and increasing employee productivity (Grasindo Widiasarana Indonesia,Jakarta,2005)

[13] Office of Social Affairs, Manpower and Transmigration of Bangkalan Regency. Profile of Technical Implementation Unit of Office of Work Training Center, 2013

[14]R. Ningsih and S. Rahayu, Assessment of Developmental Levels of Cooperatives with the DLA Method. (LSP21, Malang, 2002)

[15]R. Ningsih and S. Rahayu, Assessment of the Level of Development of Village Unit Cooperatives with the DLA Method (2004)

[16]R. Ningsih and S. Rahayu, Strategy for Improving the Performance of Cooperative Identity, UMKM Sampang Service (2009)

[17]R. Ningsih and S. Rahayu, Strategic Study of Overcoming Cooperative Bankruptcy, UTM and Sampang Cooperative Cooperative Office (2009)

[18]R. Ningsih, S. Rahayu, Performance Assessment of Women's Cooperatives. Office of Cooperatives and MSMEs (2011)

[19]R. Ningsih and S. Rahayu , Assessment and Assistance in Women's Cooperative Performance. UMKM and UTM Cooperative Service. 2015-2019 RPJMN (2012)

[20] T. Eddy, J. Technical 8, (2013)

[21] Wispandono, PUPT Proposal (Revitalization of Work Training Centers to Improve Skills of Indonesian Migrant Workers in Madura) (LPPM UTM, 2016)

[22]Zulkifli, et al. , Quality Cost Reporting to Minimize the Risk of Defective Products to Increase Company Profit (Self-Reliance, 2013) 